\title{
WILLS FORMALITIES BEYOND COVID-19: AN AUSTRALIAN-UNITED STATES PERSPECTIVE
}

\author{
KELLY PURSER, ${ }^{*}$ TINA COCKBURN ${ }^{* *}$ AND BRIDGET J CRAWFORD ${ }^{* * *}$
}

\section{INTRODUCTION}

The COVID-19 pandemic has increased focus on death and its consequences, highlighting both human mortality and the need to prepare for it, particularly for those at an increased risk, such as older persons. ${ }^{1}$ It has also highlighted the important role of technology in enabling remote access to justice and the legal system. ${ }^{2}$ In the context of estate planning, particularly valid will-making, the legal system has an important role to play; however, executing a valid will during a pandemic can be difficult given the various economic and public health restrictions, including social distancing and lockdowns. ${ }^{3}$ Accordingly, COVID-19 has focused attention on the need to increase access to valid will-making, including through the use of technology. ${ }^{4}$ Talk of death and estate planning inevitably includes discussion of both the practicalities and formal requirements for making a valid will, such as the traditional need for a physical gathering of lawyers, will-makers and witnesses, and the inevitable compliance

\footnotetext{
$*$ BA/LLB (Hons) (UNE), PhD (UNE), Senior Lecturer, Australian Centre for Health Law Research, Faculty of Law, Queensland University of Technology.

** BCom (UQ), LLB (Hons) (UQ), LLM (QUT), Grad Cert Higher Ed (QUT), Associate Professor, Co-Director Australian Centre for Health Law Research, Faculty of Law, Queensland University of Technology.

*** BA (Yale), JD (University of Pennsylvania Law School), PhD (Griffith), Professor, Elisabeth Haub School of Law, Pace University.

1 Annemarie B Docherty et al, 'Features of 20,133 UK Patients in Hospital with COVID-19 Using the ISARIC WHO Clinical Characterisation Protocol: Prospective Observational Cohort Study' (2020) 369(8250) British Medical Journal m1985: 1-2.

2 For example, by shifting to electronic filing systems and conducting entire hearings online through audiovisual platforms: for a discussion, see Michael Legg and Anthony Song, 'Commercial Litigation and COVID19: The Role and Limits of Technology' (2020) 48(2) Australian Business Law Review 159. As to online courts generally, see Richard Susskind, Online Courts and the Future of Justice (Oxford University Press, 2019). As to the potential of technology to facilitate access to justice, see Productivity Commission, Access to Justice Arrangements (Inquiry Report No 72, 5 September 2014) vol 1, 573-84 ('Access to Justice Arrangements'); Law Council of Australia, The Justice Project: Final Report (Report, August 2018) 'Overarching Themes' 42-3, 'Legal Services' 33-9 ('The Justice Project: Final Report').

3 David Horton and Reid Kress Weisbord, 'COVID-19 and Formal Wills' (2020) 73 (May) Stanford Law Review Online 18, 19, 22.

4 Ibid 18-19.
} 
challenges which arise given the COVID-19 responses. These conversations, in turn, invite consideration of the traditional functions that wills formalities purportedly serve, including the protective function, which perhaps take on greater significance given the social isolation which necessarily results from the COVID-19 public health responses, and which may have the unintended effect of heightening the risk of elder abuse. $^{5}$

Even prior to the pandemic, the utility of the formalities, especially the requirement that two witnesses be 'in the presence of' the testator, had been questioned in light of informal will applications. ${ }^{6}$ As noted, during the pandemic, compliance with traditional presence requirements has become impossible due to social distancing restrictions. ${ }^{7}$ For that reason, many states in Australia and the United States ('US') have implemented emergency measures to facilitate valid will-making during the COVID-19 pandemic. ${ }^{8}$ As societies begin to look forward, the question is whether these temporary measures, which permit remote witnessing of wills, should become the 'new normal'. Given the current practical challenges associated with satisfying the traditional wills formalities and changing societal norms about the meaning of 'presence' in light of modern technological developments, notably real time audiovisual capabilities, many jurisdictions may want to loosen the requirements for execution of a valid will. Jurisdictions like New South Wales and Queensland in Australia, with a dispensing power to uphold informal wills, or a harmless error rule in some US states, are not immune from these issues either, particularly given the costs in both time and money involved in making an application to the appropriate court for probate of an informal will. ${ }^{9}$ Access to the ability to create a valid legal document to

5 On the relationship between social isolation and elder abuse, see, eg, Bridget Lewis, Kelly Purser and Kirsty Mackie, The Human Rights of Older Persons: A Human Rights-Based Approach to Elder Law (Springer, 2020) 192.

6 See, eg, Bridget J Crawford, 'Wills Formalities in the Twenty-First Century' [2019] (2) Wisconsin Law Review 269, 271. See generally Mahlo v Hehir (2011) 4 ASTLR 515; Yazbek v Yazbek [2012] NSWSC 594; Re Yu (2013) 11 ASTLR 490; Re Nichol [2017] QSC 220; Weisbord v Rodny [2018] NSWSC 1866; Re Prien [2019] VSC 47; Re Quinn [2019] QSC 99.

7 But see Bridget J Crawford, 'Executing a Last Will and Testament During a Pandemic', The Faculty Lounge (Blog Post, 6 April 2020) <https://www.thefacultylounge.org/2020/04/executing-a-last-will-and-testamentduring-a-pandemic.html $>$, archived at $<$ https://perma.cc/Y4MU-PN6Z $>$.

8 See, eg, New York Executive Order 202.14 (7 April 2020), archived at <https://perma.cc/H3U7-F3X9>, permitting remote witnessing of wills under certain circumstances during the COVID-19 pandemic, as extended by New York Executive Order 202.59 (28 August 2020), archived at <https://perma.cc/4LWYSHZ7>. For the United States more generally, see Horton and Weisbord (n 3). For Australia, see, eg, Electronic Transactions Amendment (COVID-19 Witnessing of Documents) Regulation 2020 (NSW); COVID19 Emergency Response Bill 2020 (Qld); Justice Legislation (COVID-19 Emergency Response - Documents and Oaths) Regulation 2020 (Qld) ss 6-8; Supreme Court of Queensland, Practice Direction No 10 of 2020: Informal Wills/COVID-19, 22 April 2020; COVID-19 Omnibus (Emergency Measures) Act 2020 (Vic); COVID-19 Omnibus (Emergency Measures) (Electronic Signing and Witnessing) Regulations 2020 (Vic) pt 5. Under the Uniform Probate Code, adopted in some United States ('US') jurisdictions, a will that was not otherwise executed in accordance with the requisite formalities will nevertheless be treated as if it had been in some circumstances; thus the will can nevertheless be considered as valid and probate sought: Crawford (n 6); 
dispose of one's property at death is an issue of contemporary global significance, with COVID-19 highlighting existing challenges.

One of the simplest answers to the problems with will-making generally appears to be 'technology', that is, the virtual witnessing and electronic signing of testamentary documents through the use of a real-time audiovisual platform such as Zoom, Skype or FaceTime. This approach has been adopted in a few Australian and US jurisdictions. ${ }^{10}$ While technology may be a short-term solution to the immediate problem during times of social distancing, the question arises in relation to whether these emergency measures will and should persist post-pandemic. Examination of these matters raises associated concerns about reliance upon real-time audiovisual technologies to satisfactorily assess testamentary capacity, as well as the importance of incorporating safeguards to adequately identify and prevent undue influence, the perpetration of fraud and/or elder abuse. ${ }^{11}$

Addressing these challenges necessarily involves critical analysis and empirical exploration of the efficacy of the wills formalities and whether they continue to meet their traditional evidential, protective, cautionary and ritual functions. ${ }^{12}$ Indeed, the role of these functions has already been called into question, with some scholars arguing that only the evidentiary and channelling functions retain strong relevance in modern society..$^{13}$ The protective function, although seemingly less valuable in terms of the formalities, may continue to play a significant role in the context of the mental requirements of capacity and absence of undue influence, and as a safeguard against elder abuse. Even so, compliance with wills formalities does not provide insulation from will challenges on the grounds of a lack of testamentary capacity or undue influence. To be sure, maximising the protective function is an important goal when

Kelly Purser and Tina Cockburn, 'Wills Formalities in the Twenty-First Century: Promoting Testamentary Intention in the Face of Societal Change and Advancements in Technology' [2019] (4) Wisconsin Law Review Forward 46, 55-9.

10 For Australia, see, eg, Electronic Transactions Amendment (COVID-19 Witnessing of Documents) Regulation 2020 (NSW); COVID-19 Emergency Response Bill 2020 (Qld); Justice Legislation (COVID-19 Emergency Response - Documents and Oaths) Regulation 2020 (Qld) ss 6-8; Supreme Court of Queensland, Practice Direction No 10 of 2020: Informal Wills/COVID-19, 22 April 2020; COVID-19 Omnibus (Emergency Measures) Act 2020 (Vic); COVID-19 Omnibus (Emergency Measures) (Electronic Signing and Witnessing) Regulations 2020 (Vic) pt 5. For information about the jurisdictions in the US, see Horton and Weisbord (n 3) 24.

11 Kelly Purser et al, 'Alleged Financial Abuse of Those under an Enduring Power of Attorney: An Exploratory Study' (2018) 48(4) British Journal of Social Work 887. See also Westlaw US, American Jurisprudence $2 d$ (online at 25 September 2020) vol 3 Agency $\S 26$.

12 Crawford (n 6) 293. In relation to the dispensation of the formal requirements, see also Mellino $v$ Wnuk [2013] QSC 336; Mahlo v Hehir (2011) 4 ASTLR 515. Cf Yazbek v Yazbek [2012] NSWSC 594; Re Nichol [2017] QSC 220; Radford $v$ White [2018] QSC 306; Hatsatouris v Hatsatouris [2001] NSWCA 408; Lindsay v McGrath [2016] 2 Qd R 160.

13 Purser and Cockburn (n 9) 53-5. See Bre McAdam, 'Will Written on Tractor 65 Years Ago Celebrated by Saskatchewan Law College', The Star (online, 26 October 2013) $<$ https://www.thestar.com/news/canada/2013/10/26/will_written_on_tractor_65_years_ago_celebrated_by_sas katchewan_law_college.html $>$, archived at $<$ https://perma.cc/F9QQ-73ME $>$. 
viewed in the context of a socially distanced environment, particularly for those people who live alone and who may be experiencing heightened vulnerability and risk of abuse because of social isolation.

This essay enters the discussion around the emergency responses to COVID-19 by bringing a new focus to the shape of post-pandemic will-making. Part II examines the purpose of traditional wills formalities and their continued efficacy (or inefficacy) in a modern world. Part III provides an overview of a range of international emergency responses to the need to execute valid wills during the pandemic. Part IV then makes observations about will-making post-pandemic, including pathways out of the current emergency responses into measures that could inform the 'new normal'.

\section{TRADITIONAL FUNCTIONS OF THE FORMALITIES AND MODERN WILL-MAKING}

To a certain extent, the law of will-making is in flux both in Australia and the US. ${ }^{14}$ New technologies invite questions about expanding will-making accessibility. That has led, for example, to the promulgation in the US of an Electronic Wills Act in July 2019. ${ }^{15}$ Prior to the pandemic, it is not clear how many states were moving to consider the adoption of similar provisions. In most other international jurisdictions, there has been no real appetite for technology-driven reform; there was definitely no sense of urgency. For example, in the recent review of the law of wills of the United Kingdom, the Law Commission gave provisional support for adopting a dispensing power rather than undertaking the extensive legislative reform required to implement an exclusively intention-based model (and thus forsaking all formal requirements). ${ }^{16}$

In Australia, as in the US, the execution of wills could be much improved upon, although rigorous data around will-making (pre-, during and post-pandemic) would offer valuable insights as to the prevalence of execution-related problems. ${ }^{17}$ The formal requirements to make a valid will can vary significantly between and among international jurisdictions, and within one country's federalist system, as is true in Australia and the US. ${ }^{18}$ Although the specifics of traditional will formalities vary, their traditionally stated purposes, in both the US and Australia, are fourfold: they are

14 Horton and Weisbord (n 3) 18-19; Purser and Cockburn (n 9) 55-9.

15 Uniform Electronic Wills Act (Uniform Law Commission, 2019).

16 Law Commission, 'Making a Will' (Consultation Paper No 231, 2017) 13, 98-102<https://s3-eu-west2.amazonaws.com/lawcom-prod-storage-11jsxou24uy7q/uploads/2017/07/Making-a-will-consultation.pdf> ('Making a Will').

17 David Horton has already begun some of this excellent work. See, eg, David Horton, 'Partial Harmless Error for Wills: Evidence from California' (2018) 103(5) Iowa Law Review 2027. See also Cheryl Tilse et al, 'WillMaking Prevalence and Patterns in Australia: Keeping It in the Family' (2016) 50(3) Australian Journal of Social Issues 319; Ben White et al, 'Estate Contestation in Australia: An Empirical Study of a Year of Case Law' (2015) 38(3) University of New South Wales Law Journal 880.

Purser and Cockburn (n 9) 48-50. 
designed to serve evidentiary, cautionary or ritual, protective, and channelling functions. ${ }^{19}$ Further, some general minimal formal commonalities do emerge within the overarching functional framework. Wills, for instance, must generally be in writing ${ }^{20}$ and signed by the testator or someone 'in the presence of' (or 'the conscious presence of') and directed by the testator. ${ }^{21}$ The testator's signature (or acknowledgement of that signature) must then take place 'in the presence of' two or more witnesses (or a notary, in some states). ${ }^{22}$

The requirement of 'presence' is a clear theme running throughout wills formalities and traditional functions across jurisdictions. The requirement of presence clearly serves the evidentiary function in providing that at least two adults must attest to the fact that they saw the testator sign the will. Similarly, presence also meets the channelling function as the presence of two witnesses goes to ensuring the integrity (and regularity) of the will-making process. ${ }^{23}$ It also promotes the protective function in that there should be two independent witnesses with nothing to gain from the dispositions contained in the testamentary document. Thus, there is a theoretical buffer between, for instance, the testator and any undue influence (although the utility of witnesses as a preventative measure, particularly in the context of elder abuse, is questionable). The 'presence' requirement also helps to carry out the cautionary or ritual purpose, with the solemnity of the occasion reinforcing the importance of the will-making act given that will-making can have a positive psychological effect. ${ }^{24}$

There is therefore no doubt as to the role and importance of the presence requirement in promoting valid will-making. This is not to say that this is not without its difficulties, given, for example, the frequency of wills failing to meet this requirement. There is also a danger that otherwise valid wills could be held to be invalid for falling short of the required presence formalities if a doctrine of strict compliance is adopted. However, in jurisdictions that have a dispensing power, such as New South Wales and Queensland in Australia and Michigan in the US, there is arguably a solution, namely to make an application for an informal will, although this can be costly in terms of both time and money. ${ }^{25}$ It is also important to note that even jurisdictions with dispensing powers, such as New South Wales, Queensland and

\footnotetext{
19 Crawford (n 6) 286-90.

20 See, eg, Succession Act 2006 (NSW) s 6; Succession Act 1981 (Q1d) s 10(2)(a); Uniform Probate Code (Uniform Law Commission, 1969, rev 2019) § 2-502(a)(1).

21 See, eg, Succession Act 2006 (NSW) s 6; Succession Act 1981 (Qld) s 10(2)(b)(i)-(ii); Uniform Probate Code (Uniform Law Commission 1969, rev 2019) § 2-502(a)(2).

22 See, eg, Succession Act 2006 (NSW) s 6; Succession Act 1981 (Qld) s 10(4); Uniform Probate Code (Uniform Law Commission 1969, rev 2019) § 2-502(a)(3)(A).

23 Purser and Cockburn (n 9) 55.

24 Ibid 51-4.

25 Ibid 62; Horton and Weisbord (n 3) 25. For dispensing legislation, see Succession Act 2006 (NSW) s 8; Succession Act 1981 (Qld) s 18.
} 
Michigan, nevertheless implemented emergency provisions enabling the electronic signing and audiovisual witnessing of wills to occur as a result of the pandemic. ${ }^{26}$

It is also commonplace (but not mandatory) in various jurisdictions, including in the US and Australia, to have an attestation clause in professionally drafted wills. Such a clause gives rise to the rebuttable presumption of due execution, that is, the will is prima facie regular and complies with the requisite formalities thus fulfilling an evidentiary function. ${ }^{27}$ This presumption is designed to promote cost and timeeffective grants of probate (where appropriate), which traditionally requires the production of the (sole) original will to the court for the will to be proved as the last will and testament of the deceased. ${ }^{28}$

The role of the attestation clause and the importance attached to the role of the solicitor are significant. As will be seen below in the discussion of the emergency responses, in Queensland, for example, audiovisual witnessing has been adopted but the categories of people who can witness are restricted. ${ }^{29}$ Analogously, in the US, in the State of Connecticut, remote will execution must be supervised by an attorney. ${ }^{30}$ Both of these examples raise the issue of accessibility. While prima facie, the ability to more easily avail oneself of valid will-making has been extended in many jurisdictions, the question must be asked as to whether this will be the outcome. If there is a requirement of witnesses falling within designated categories (as in Queensland) or attorney supervision (as in Connecticut), do the emergency provisions truly have the effect of widening participation and access to quality will-making (and, in the case of jurisdictions with a dispensing power, thus reducing later court applications in relation to validity and/or construction issues)? Or does the legal reform just make will execution more convenient and possible for those who already would have attended upon a solicitor or engaged an attorney but now cannot owing to COVID-19 restrictions? In thinking about the 'new normal', this question requires further thought and, importantly, empirical research into the reasoning behind people's approaches to will-making.

Another common theme emerging from wills formalities across jurisdictions is the traditional requirement that a witness cannot be an interested beneficiary, that is, traditionally a beneficiary cannot witness the will and, if they do, they will be

26 Horton and Weisbord (n 3) 27; Electronic Transactions Amendment (COVID-19 Witnessing of Documents) Regulation 2020 (NSW); COVID-19 Emergency Response Bill 2020 (Q1d); Justice Legislation (COVID-19 Emergency Response - Documents and Oaths) Regulation 2020 (Qld) ss 6-8; Michigan Executive Order No 2020-74 (5 May 2020), archived at <https://perma.cc/K36C-DGVJ>.

27 See, eg, Succession Act 1981 (Qld) s 10(9); Westlaw US, American Jurisprudence 2d (online at 25 September 2020) vol 79 Wills $\S 234$ (attestation clauses in US wills generally). See also Re Unsworth (1974) 8 SASR

312. On rebutting the presumption, see, eg, Burnside v Mulgrew [2007] NSWSC 550.

Purser and Cockburn (n 9) 60.

COVID-19 Emergency Response Bill 2020 (Q1d); Justice Legislation (COVID-19 Emergency Response-

Documents and Oaths) Regulation 2020 (Q1d) s 5, which includes, for example, an Australian legal practitioner, justice or commission for declarations or a notary public.

See Connecticut Executive Order No 7Q (30 Mar 2020), archived at <https://perma.cc/MAV4-2NZ7>. 
disqualified from taking as a beneficiary under the will. ${ }^{31}$ There is an overt protective function to this formality, although, again, the theoretical intent and the practical reality can differ, particularly when considering undue influence and unconscionable conduct as well as the rates of elder abuse. ${ }^{32}$ The interested beneficiary rule was arguably a catalyst behind the emergency provisions, given many people live with those they would name in their wills.

The current COVID-19 pandemic has therefore drawn the accessibility of valid will-making sharply into focus. Social distancing restrictions mean that people may not be able to avail themselves of any, let alone two, witnesses in order to make a valid will. COVID-19 has thus served a two-fold purpose in relation to will-making. Firstly, it has highlighted the practical shortcomings with arguably antiquated systems that have required emergency responses to ensure valid documents evidencing clear testamentary intention can be made. Most frequently these emergency responses have involved authorising electronic signatures and real-time virtual or audiovisual witnessing (discussed further in the next Part). Secondly, there is a broader societal problem about will-making accessibility which, now front and centre, cannot be allowed to disappear, especially given the general policy approach of favouring testacy over intestacy. ${ }^{33}$

In the context of the policy of favouring testacy, it is important to note that there are fixed-share intestacy provisions in both Australian and US jurisdictions. ${ }^{34}$ Intestacy is a default rule that roughly attempts to effectuate the intent of the average decedent. However, while these provisions are ideally a reflection of societies' values, which informs the differences in provisions within the various jurisdictions, in reality they have not kept pace with societal changes, cultural norms, nor the changing concept of 'family', which reinforces the need to facilitate access to valid will-making. ${ }^{35}$ For example, in Queensland, a 2014 case determined that a person recognised as a 'child' under Aboriginal culture is not a 'child' for the purposes of intestacy (or family

31 Succession Act 1981 (Qld) s 11; Westlaw US, American Jurisprudence $2 d$ (online at 25 September 2020) vol 79 Wills § 264. Cf Uniform Probate Code § 2-505(b) (Uniform Law Commission, 1969, rev 2019). Purser and Cockburn (n 9) 53-5.

33 See, eg, Succession Act 1981 (Qld) ss 33B, 33N, 33P; Wehrheim v Golden Pond Assisted Living Facility, 905 So 2d 1002, 1007 (Sawaya J) (Fla Dist Ct App, 2005); Re Ikuta, 639 P 2d 400, 406 (Richardson CJ) (Haw, 1981).

34 In Australia, see Administration and Probate Act 1929 (ACT) pt 3A; Succession Act 2006 (NSW) ch 4; Administration and Probate Act 1969 (NT) pt III divs 4, 4A, 5; Succession Act 1981 (Qld) pt 3, sch 2; Administration and Probate Act 1919 (SA) pt 3A; Intestacy Act 2010 (Tas); Administration and Probate Act 1958 (Vic) pt 1A; Administration Act 1903 (WA) ss 12A-15. In most US jurisdictions, upon intestacy, typically the spouse will take some or all of the descedant's estate, with children, parents, and other collateral blood relations then in line to inherit: see Uniform Probate Code §§ 2-102, 2-103 (Uniform Law Commission 1969, rev 2019).

35 See Fiona Burns, 'The Changing Patterns of Total Intestacy Distribution between Spouses and Children in Australia and England' (2013) 36(2) University of New South Wales Law Journal 470. On intestacy provisions and Indigenous peoples in Australia, see Prue Vines, 'Wills as Shields and Spears: the Failure of Intestacy Law and the Need for Wills for Customary Law Purposes in Australia' (2001) 5(13) Indigenous Law Bulletin 16. 
provision) legislation. ${ }^{36}$ Similarly, in the US state of Georgia, only children who are biologically related to the decedent or who are formally adopted may inherit under the laws of intestacy. ${ }^{37}$ Accordingly, when an African-American man died intestate, the woman he had equitably adopted as a child and raised, whom he referred to as his 'daughter', was not permitted to inherit. ${ }^{38}$

\section{III 'IN THE PRESENCE OF’ - AN INTERNATIONAL RESPONSE}

As identified above, the key formality affected by COVID-19 is the requirement of witnesses being 'in the (conscious) presence of' the testator. Whether that presence needs to be physical is not a new question. Courts have long required that the presence be physical, measuring traditional presence by a 'line of sight' test. ${ }^{39} \mathrm{New}$ technologies raise the issue of whether 'presence' can (and should) be virtual. What COVID-19 has done is make this an urgent issue that needs to be addressed in order to facilitate valid will-making and to avoid not only intestacy, but also sometimes costly applications for recognition of informal wills. Consequently, emergency responses have been introduced in a number of jurisdictions worldwide including in, for example, the US, Australia, Canada and New Zealand. ${ }^{40}$ Some jurisdictions, such as Queensland, have stated that the measures apply to not just making a will but also to alterations, revocations and the revival of wills.$^{41}$ The United Kingdom Ministry of Justice has recently issued a press release $^{42}$ and guidance on making wills using video

36 Succession Act 1981 (Qld) pt 3, sch 2; Eatts v Gundy [2015] 2 Qd R 559.

37 Georgia Code $\$ 53-3-1$.

38 O'Neal v Wilkes, 439 SE 2d 490 (Ga, 1994).

39 See, eg, Burney v Allen, 34 SE 500 (NC, 1899).

40 For the US, see Horton and Weisbord (n 3). For Australia, see, eg, Electronic Transactions Amendment (COVID-19 Witnessing of Documents) Regulation 2020 (NSW); COVID-19 Emergency Response Bill 2020 (Qld); Justice Legislation (COVID-19 Emergency Response - Documents and Oaths) Regulation 2020 (Qld) ss 6-8; Supreme Court of Queensland, Practice Direction Number 10 of 2020: Informal Wills/COVID-19, 22 April 2020; COVID-19 Omnibus (Emergency Measures) Act 2020 (Vic); COVID-19 Omnibus (Emergency Measures) (Electronic Signing and Witnessing) Regulations 2020 (Vic) pt 5. Canada: British Columbia, Minister of Public Safety and Solicitor General, Ministerial Order No M161 (19 May 2020), archived at $<$ https://perma.cc/XU6X-TE3G>; Alberta, Minister of Justice and Solicitor General, Ministerial Order 39/2020 (15 May 2020), archived at <https://perma.cc/9Z2T-FG6Y >. New Zealand: Explanatory Note, Epidemic Preparedness (Wills Act 2007 - Signing and Witnessing of Wills) Immediate Modification Order 2020 (NZ), archived at $<$ https://perma.cc/42QZ-K5SQ>.

41 COVID-19 Emergency Response Bill 2020 (Qld); Justice Legislation (COVID-19 Emergency ResponseDocuments and Oaths) Regulation 2020 (Qld) s 6.

42 Ministry of Justice (UK), 'Video-Witnessed Wills to Be Made Legal during Coronavirus Pandemic' (Press release, 25 July 2020) <https://www.gov.uk/government/news/video-witnessed-wills-to-be-made-legal-duringcoronavirus-pandemic $>$. 
conferencing. ${ }^{43}$ The press release states that legislation will be enacted to amend the Wills Act 1837 (UK) which will provide that where wills must be signed in the 'presence' of at least two witnesses, their presence can be either physical or virtual, via video-link. Wills will still need to be signed by two witnesses who are not beneficiaries and electronic signatures will not be permitted. The legislation will apply retrospectively to wills made since 31 January $2020^{44}$ (except in cases where a Grant of Probate has already been issued in respect of the deceased person, and the application is already in the process of being administered) and apply to wills made up to two years from when the legislation comes into force (that is, until 31 January 2022). The duration can be shortened or extended if deemed necessary, in line with the approach adopted for other coronavirus legislative measures. Once the legislation ceases to be operative, the physical witnessing requirements will resume.

Some jurisdictions that have adopted emergency measures for will executions have chosen to restrict the witnessing role to specific categories of witness such as a lawyer, justice of the peace, commissioner for declarations and/or notary public. ${ }^{45}$ Generally, the witness is then required to certify that the document was signed in accordance with the regulations either on the document in question or in a separate certificate. ${ }^{46}$ On the one hand, this was done (presumably) with the intention of fulfilling the protective function, particularly in light of providing a safeguard in the context of concerns about capacity, undue influence, fraud and elder abuse. However, the restriction to being or including a 'special witness' means that it is questionable whether these provisions have widened participation in will-making beyond those who would have availed themselves of it pre-COVID. This is important when critically considering the utility of these measures post COVID-19.

Individual jurisdictions have also taken the opportunity to include sunset clauses. The New Zealand provisions, for example, will cease when the Epidemic Preparedness (COVID-19) Notice 2020 (NZ) expires or is revoked ${ }^{47}$ while other

43 Ministry of Justice (UK), 'Guidance on Making Wills Using Video Conferencing' (Press Release, 25 July 2020) $<$ https://www.gov.uk/guidance/guidance-on-making-wills-using-video-conferencing $>$ ('Guidance on Making Wills Using Video Conferencing').

44 This is the date of the first registered COVID-19 case in England and Wales.

45 See, eg, British Columbia, Minister of Public Safety and Solicitor General, Ministerial Order No M161 (19 May 2020), archived at $<$ https://perma.cc/XU6X-TE3G $>$; COVID-19 Emergency Response Bill 2020 (Qld); Justice Legislation (COVID-19 Emergency Response - Documents and Oaths) Regulation 2020 (Qld) s 5.

46 For specific provisions in Australia, see, eg, Electronic Transactions Amendment (COVID-19 Witnessing of Documents) Regulation 2020 (NSW); COVID-19 Emergency Response Bill 2020 (Qld), Justice Legislation (COVID-19 Emergency Response - Documents and Oaths) Regulation 2020 (Qld) ss 6-8, pt 4; Supreme Court of Queensland, Practice Direction Number 10 of 2020: Informal Wills/COVID-19, 22 April 2020; COVID-19 Omnibus (Emergency Measures) Act 2020 (Vic); COVID-19 Omnibus (Emergency Measures) (Electronic Signing and Witnessing) Regulations 2020 (Vic) pt 5.

47 Explanatory Note, Epidemic Preparedness (Wills Act 2007 - Signing and Witnessing of Wills) Immediate Modification Order 2020 (NZ), archived at <https://perma.cc/VMH4-69SS >. 
jurisdictions, such as Queensland and New York, have given a specific date. ${ }^{48}$ Such clauses are prudent given the emergency nature of the measures which were implemented urgently, without widespread consultation or consideration of rigorous evidence in relation to their utility and potential adverse consequences, and without the debate generally associated with law reform. What needs to happen now is the more careful consideration of what could and should inform the post-pandemic "new normal', including whether the extension to virtual witnessing should become a permanent alternative. This is particularly the case in geographically large countries with widely dispersed populations, including in rural and remote areas, such as the US and Australia, wherein sheer physical distance from urban centres can be an impediment to receiving professional estate planning advice. Practical implementation of technological solutions is, of course, predicated upon digital literacy and the appropriate technology being available and affordable, which is not always the case. ${ }^{49}$

Practical challenges will also arise, for example, in relation to the use of copies when seeking probate where, traditionally, the production of the (that is, only) original will was required. For example, most jurisdictions have made provisions for the testator and each of the witnesses to be able to sign either their own copies or a scanned copy of the will when virtually witnessing the document. Consequently, there could be anywhere up to three versions of a will if electronically signed and/or witnessed, with the testator and each of the two witnesses potentially 'signing' different documents. ${ }^{50}$ The questions therefore arise: if there are two remote witnesses and three signed documents in total (including the testator's signed document), will all three documents be required to be produced for probate to be granted, and what happens if one of those copies is lost? The (rebuttable) presumption of destruction thus warrants consideration. The presumption is designed as a protective mechanism for testamentary freedom wherein the absence of the original will was presumed to equate to the document's destruction by the testator. ${ }^{51}$ However, rebuttal evidence can be led

48 COVID-19 Emergency Response Bill 2020 (Qld); Justice Legislation (COVID-19 Emergency Response Documents and Oaths) Regulation 2020 (Qld) s 27; New York Executive Order No 202.59 (28 August 2020), archived at $<$ https://perma.cc/4LWY-SHZ7> (extending New York Executive Order No 202 to 27 September, 2020). See also the proposed UK legislation: 'Guidance on Making Wills Using Video Conferencing' (n 43). Julian Thomas, Chris K Wilson and Sora Park, 'Australia's Digital Divide Is Not Going Away' The Conversation (online, 29 March 2018) <https://theconversation.com/australias-digital-divide-is-not-goingaway-91834>.

50 Each jurisdiction has adopted their own process. For specifics in Australia see, eg, Electronic Transactions Amendment (COVID-19 Witnessing of Documents) Regulation 2020 (NSW); COVID-19 Emergency Response Bill 2020 (Qld); Justice Legislation (COVID-19 Emergency Response - Documents and Oaths) Regulation 2020 (Qld) ss 6-8, pt 4; Supreme Court of Queensland, Practice Direction Number 10 of 2020: Informal Wills/COVID-19, 22 April 2020; COVID-19 Omnibus (Emergency Measures) Act 2020 (Vic); COVID-19 Omnibus (Emergency Measures) (Electronic Signing and Witnessing) Regulations 2020 (Vic) pt 5; British Columbia, Minister of Public Safety and Solicitor General, Ministerial Order No M161 (19 May 2020) s 3(5), archived at $<$ https://perma.cc/XU6X-TE3G $>$.

51 See Curley v Duff (1985) 2 NSWLR 716; Cahill v Rhodes [2002] NSWSC 561; Re Cardie (2013) 11 ASTLR 379; Re Middleton [2019] QSC 128; Re Fawkes [2020] QSC 200. 
as to a lack of destruction or a lack of intention to destroy on behalf of the testator. ${ }^{52}$ The introduction of the emergency provisions gives rise to the question as to what will now not only give rise to the presumption (for example, is the loss of one of the signed documents sufficient or would all copies need to be lost or presumed destroyed), but also the types of rebuttable evidence necessary to displace the presumption, as well as associated tracing difficulties to try to locate lost versions. Furthermore, could this, and other as yet unforeseen practicalities, inadvertently serve to thwart the reason that the emergency responses were introduced: as a means of protecting testamentary freedom?

\section{POST COVID-19 - WILLS AND THE ROLE OF TECHNOLOGY}

In post-pandemic will-making, it will be important to actively evaluate the emergency measures and consider which of these, if any, should inform the "new normal'. Even pre-pandemic, the increasing focus and dependency on technology has arguably already challenged the traditional notion of will formalities and the fulfilment (or non-fulfilment) of the associated functions, and has been seen in relation to other legal documents such as contracts and affidavits. ${ }^{53}$ In order to promote the accessibility of will-making post-pandemic, it will be critical to examine the functions of the formalities and the two main approaches to enforcing them. A formalist approach requires strict adherence to the will formalities. Alternatively, a functionalist approach undeniably provides primacy to testamentary intention; it is embodied in the intentionbased dispensing power and harmless error rules. ${ }^{54}$ Under those approaches, the lack of formal compliance will not defeat a clear testamentary intention. These cases also have an element of judicial oversight which arguably, even absent the formal requirements, serves some of the traditional functions of wills formalities. ${ }^{55}$ However, as noted, not all jurisdictions have a dispensing power or harmless error statute. Furthermore, even where such a power or statute does exist, there is still a need to

52 In Australia generally five matters need to be established, including: there was will; that will revoked all previous wills; the presumption of destruction is rebutted; evidence of the terms of the will; and evidence of due execution or the testator's intention that the document constitute their will: Re Cardie (2013) 11 ASTLR 379,381 [14] (de Jersey CJ). For a recent example of a case where the presumption was rebutted, and the evidence relevant to rebuttal, see Re Fawkes [2020] QSC 200, [14]-[22] (Davis J). Under the laws of US states, there is a similar presumption that a lost will has been destroyed with the intent to revoke it: see Restatement (Third) of Property (1999) § $4.1 \mathrm{cmt}(\mathrm{j})$.

53 See, eg, Stuart v Hishon [2013] NSWSC 766; Electronic Transactions Act 1999 (Cth); Electronic Transactions Act 2001 (ACT); Electronic Transactions Act 2000 (NSW); Electronic Transactions (Northern Territory) Act 2000 (NT); Electronic Transactions (Queensland) Act 2001 (Qld); Electronic Communications Act 2000 (SA); Electronic Transactions Act 2000 (Tas); Electronic Transactions (Victoria) Act 2000 (Vic); Electronic Transactions Act 2003 (WA).

54 'Making a Will' (n 16) 13.

55 Ibid. For recent informal will cases, see, eg, Re Nichol [2017] QSC 220; Weisbord v Rodny [2018] NSWSC 1866; Re Quinn [2019] QSC 99. 
bring a court proceeding; this can be costly in terms of time and money; and it occurs during a time when people are often grieving the loss of a loved one. Significantly, the main witness (the testator) is also deceased, so, as is always the case with wills litigation, there is a danger of not being able to satisfactorily evidence the requisite testamentary intention.

The sometimes prohibitive costs involved with will-making and the fact that making a will can be challenging for a multitude of other reasons together underscore the difficulties that can occur in ensuring compliance with the formalities. ${ }^{56}$ Both in Australia and in the US, one response to the general accessibility issues involved with making a valid will is the increase in 'do-it-yourself' wills, including 'will-kits' and online wills, which frequently fail to meet the traditional formal requirements. The result therefore is that, although ostensibly permitting the exercise of testamentary freedom, such documents can have the practical effect of preventing this freedom from being effectuated unless there is evidence of a clear testamentary intent as required for an application to dispense with the formalities. ${ }^{57}$ Thus, instead of promoting willmaking accessibility, these types of wills likely often instead defer (and usually increase) the cost; instead of paying for legal advice to make the will during their lifetime, the decedent (or the decedent's estate, more accurately) 'pays' for legal advice post mortem, through legal proceedings to determine the validity of the document or to construe its meaning. ${ }^{58}$

The pre-eminence of the role of intention in will-making is indisputable. Does this, however, mean the abolition of traditional formalities as anachronistic remnants from a different time? Or do they still have a valid role to play in informing the 'new normal' post pandemic? Arguably the answer remains yes: the formalities will play a role in a post-COVID society where technology has crept into the signing and witnessing psyche of valid will-making under the emergency provisions implemented during the times of COVID-19. This is because the formalities facilitate, through the use of the various presumptions, the more expeditious and cost-effective grants of probate in a society that still promotes testate estates over fixed-share intestacy provisions which can give rise to expensive will contestations. ${ }^{59}$ Two of us believe that the evidentiary, channelling and protective functions (when considered in connection with the mental requirements, most notably testamentary capacity and undue influence) are served by formalities. ${ }^{60}$ One of us is less sanguine, but not ready to eliminate formalities entirely. ${ }^{61}$

Technological innovations ideally promote will-making accessibility to people who would otherwise not have been able to execute a valid document evidencing their

Crawford (n 6) 291.

See, eg, Uniform Probate Code § 2-503 (Uniform Law Commission, 1969, rev 2019).

Purser and Cockburn (n 9) 60-1. See also Re Standish [2018] VSC 629; Radford v White [2018] QSC 306.

White et al (n 17); 'Making a Will' (n 16) 73-4.

Purser and Cockburn (n 9) 64.

Crawford (n 6) 293. 
testamentary intentions. However, and this is why the use of sunset clauses in the emergency provisions is so important, there are serious issues that require dedicated consideration before making the emergency responses permanent measures. Notably, although the intention is to increase will-making accessibility, evidence is needed as to whether this, in fact, occurred. Were people who made wills under emergency provisions those who would have made a will anyway, or did access to will-making increase? Was will-making behaviour encouraged by emergency procedures themselves, or was it driven by the practical (and real) fear of possible death during a pandemic? Further, there is a real risk that well-intentioned temporary measures or longer-term changes that make use of technological advancements could be used as vehicles for abuse, particularly of vulnerable older persons and those who may be socially isolated, and possibly obscure issues of capacity, undue influence and fraud. ${ }^{62}$ Therefore, although it is arguable as to whether the formal requirements themselves continue to fulfil a meaningful protective purpose, it will be important to recognise that the formalities can be useful for other reasons. ${ }^{63}$

\section{CONCLUSION}

COVID-19 has sharply highlighted the issues surrounding will-making accessibility, particularly in light of the traditional formalities. These questions existed pre-COVID, but the questions now demand an immediate response, as emergency provisions put in place during the pandemic may not last permanently. Generally speaking, some people are still choosing to die intestate, do not want to make a will, may not know how to begin or may be too daunted by the process of will-making to begin. Furthermore, there has been a rise in 'home-made' wills, including the use of readily available will-kits and online wills. A focus on testate rather than intestate estates still dominates policy discussions of succession laws in both Australia and the US. Another guiding force is testamentary intention, as an exercise of testamentary freedom, subject to some limitations such as family provision legislation.

Although technologies may bring valid will-making to a wider audience, they may (or may not) give effect to the testator's testamentary intentions. This can be as a result of construction issues or failure to meet the formal requirements for will execution. As can be seen in jurisdictions such as New South Wales and Queensland in Australia (which have dispensing powers) or US states (that have a harmless error statute), while offering an opportunity to give effect to testamentary intentions that would otherwise fail, implementing technological solutions and non-traditional will-making can also

See generally Australian Law Reform Commission, Elder Abuse: A National Legal Response (Final Report No 131, May 2017) ch 8; Access to Justice Arrangements (n 2); The Justice Project: Final Report (n 2) pt 1 Older People. 
result in judicial proceedings that may be financially costly, far more so than making a traditionally valid will at the outset. Further, the use of homemade wills may also mean that fewer people seek out professional estate planning advice. Instead of increasing effective testamentary dispositions, the result of the use of non-traditional wills may inadvertently cause an increase in costly litigation and will challenges. ${ }^{64}$

The advent of electronic signing and real time audio-visual witnessing in response to the crisis thus leads to a simple question: why cannot this be done in non-crisis times, with the intention of increasing will-making accessibility? Responding to such a question requires careful and considered thought. This essay has sought to address this question by considering the role of traditional formalities and whether those formalities are still 'fit for purpose' in a modern society, particularly in relation to the presence requirement for witnesses. Consequently, select global will-making responses to the COVID-19 crisis illuminate the utility of considering such responses in a post-COVID world.

Future empirical research about will-making will help determine whether the new measures have indeed increased access to will-making. Regardless of the findings, such measures should not be blindly adopted as the new normal. Questions regarding assessments of the testator's capacity, as well as safeguarding the testator against fraud and undue influence, will require detailed and critical thought, especially given the increasing rates of elder abuse. Nevertheless, COVID-19 has demonstrated that while virtual wills may be possible, efforts to imagine the 'new normal' post-pandemic need to critically engage with the issues raised here. It may be that some of the measures can be implemented permanently as a way to begin to address larger issues in relation to widening access to will-making. 